\title{
Scientific-Research Cluster as a form of Knowledge Transfer
}

\section{Znanstvenoistraživački klaster kao oblik prijenosa znanja}

\author{
Preliminary paper • Prethodno priopćenje \\ Received-prispjelo: 30. 6. 2011. \\ Accepted-prihvaćeno: 22. 11. 2011. \\ UDK: $630 * 79$ \\ doi:10.5552/drind.2011.1120
}

\begin{abstract}
The issue of knowledge transfer within organizations acting in the economic sphere is high on the agenda at this time. The reason is that on the one hand, considerable public funds are spent for different forms of research, but on the other hand, the effectiveness of these resources within the industry is comparatively low. Developing an efficient technology transfer is along-term activity. The concept of technology transfer is a narrowed concept. The wider concept is the transfer of intellectual property. The suggested model would contain substantive, structural, and relationship functional definition of a scientific-research cluster as a new form of knowledge transfer in the industrial sphere. The stated issue is solved within the project of the $7^{\text {th }}$ EU Framework Programme, where the author of the paper participates as a co-project manager. The proposed scientific-research cluster is to serve as a model for countries of Central and Eastern Europe.
\end{abstract}

Key words: knowledge transfer, economic sphere, technology transfer

SAŽETAK • Pitanje prijenosa znanja u organizacije na području gospodarstva trenutačno je visoko na prioritetnoj listi. Razlog je ponajprije to što se znatna sredstva ulažu u različite oblike istraživanja, no unatoč tome učinkovitost rezultata tih istraživanja u industriji je relativno niska. Povećanje učinkovitosti prijenosa znanja dugotrajna je aktivnost. Koncept transfera tehnologija je uzak. Transfer intelektualnog vlasništva mnogo je širi koncept. Predloženi model sadržava značenjske definicije, strukturne definicije i definicije funkcionalnih odnosa znanstvenoistraživačkog klastera kao novog oblika prijenosa znanja u industrijsko okruženje. Promatrani problem rješava se unutar projekta 7. EU Okvirnog programa, u kojemu autorica rada sudjeluje kao koprojekt menadžer. Opisani znanstvenoistraživački klaster predložen je kao model za zemlje srednje i istočne Europe.

Ključne riječi: prijenos znanja, gospodarsko okruženje, prijenos tehnologije

\section{INTRODUCTION \\ 1. UVOD}

One of the fundamental problems of increasing the effectiveness of organizations today includes the issues concerning the knowledge transfer into organizations operating in the economic sphere. On the one hand, at present considerable resources are spent both from the public resources and from the funds of economic organizations for the various forms of research, on the other hand, the effectiveness of these funds is low. The experience of advanced industrialized countries shows that it often takes several years prior to building an effective technology transfer function (Figure 1). The concept of technology transfer is a narrow concept, and actually the wider concept includes the tran-

\footnotetext{
${ }^{1}$ Author is assistant professor at Faculty of Mass Media Communication, University of Ss Cyril and Methodius in Trnava, Trnava, Slovak Republic.

Autorica je docentica Fakulteta za komunikacije u masovnim medijima, Sveučilište Ćirila i Metoda u Trnavi, Trnava, Slovačka.
} 


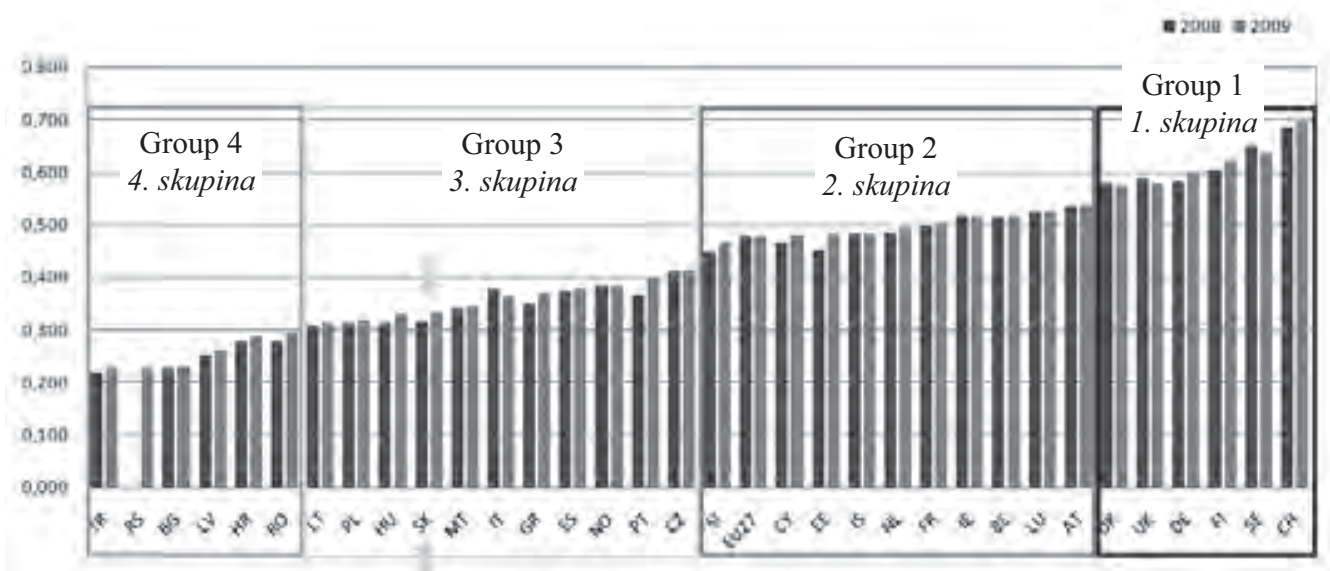

Figure 1 European Innovation Scoreboard 2009, Published 2010, www.proinno-europe.eu, Note: The SII Slika 1. Europska tablica inovacija 2009, izdanje 2010, www.proinno-europe.eu, Note: The SII

sfer of intellectual and industrial property. This transfer (besides technology it relates to other forms of intellectual and industrial property, particularly to materialization of intellectual and industrial property in developing new products, etc.) should be an effective implementation of aproactive management system of the intellectual and industrial property.

This requirement has recently been underestimated.

At present, however, the main challenge is to: - provide activities of knowledge transfer (particularly in research organizations, regardless of their funding, a clear commitment of the top management of these organizations);

- provide management of the ownership regimes of such knowledge, particularly the results of development and research in order to clearly determine the entity responsible for the use of intellectual and industrial property;

- be involved in the implementation of this commitment of scientists and researchers to develop a structure that is, from the professional point of view, prepared for the maintenance of effective relations of research and development organizations of all parties involved (stakeholders).

Regardless of the ownership, legal and organizational form of research and development organizations, at present an effective form of resolving the above issues is considered to be the establishment of so-called „knowledge transfer offices“ (Knowledge Transfer Office-KTO). These organizations have a different legal and organizational form, but the role that is performed in the course of their activities is common. Formulating the mission of these organizations, their structures and networking is preceded by several key assumptions, which apply to all these organizations.

Transfer of knowledge is an important function, which requires the Professional management. This function must be adequately secured by resources, by a long-termcommitment of providing an access to the necessary funds and expertise.

KTO increases the effectiveness of research organizations in the transfer of knowledge to maximize the benefits of these organizations for the society.

The most effective approach to the transfer of knowledge lies in creating a solid link among KTO, research organizations, as well as the researchers themselves.

Acquiring the knowledge, tools and techniques in the field of knowledge transfer can take several years and it is therefore important to allow the exchange of the best experience and practices not only between individual KTO, research organizations, but also with the industrial practice.

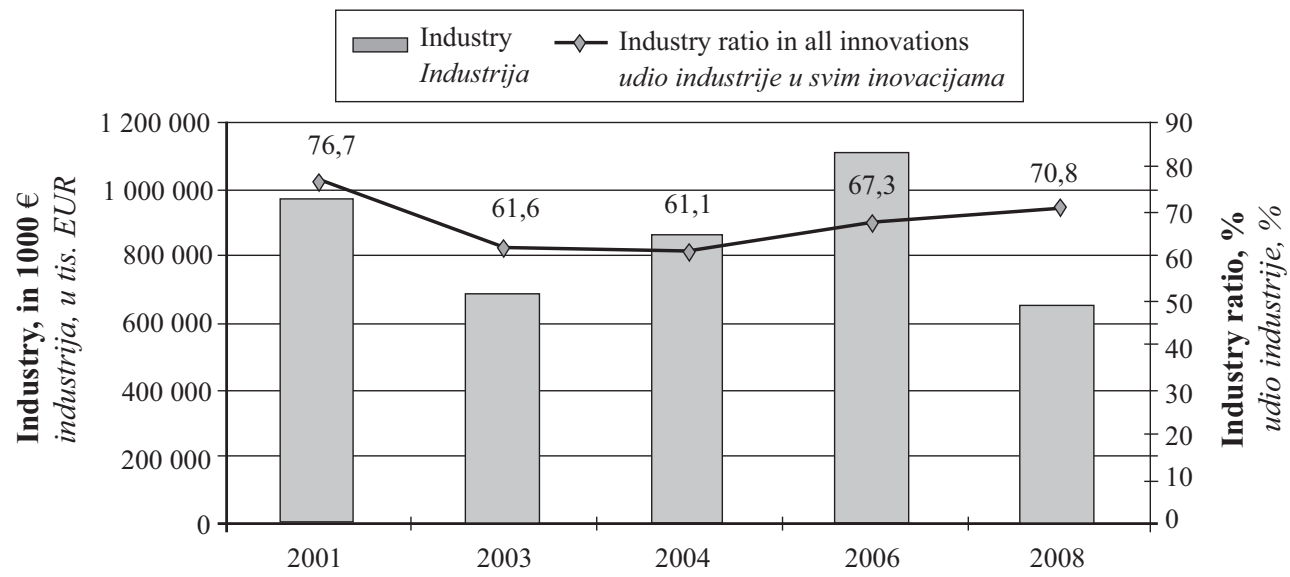

Figure 2Trend of investments to industry in Slovakia (in $000 €$ ). Source: ŠÚ SR

Slika 2. Trend investicijskih ulaganja u industriju Slovačke (u tis.EUR). Izvor: ŠU SR 


\subsection{Research problem}

\subsection{Problematika istraživanja}

The knowledge transfer office (KTO) includes different organizations that operate in the active transfer of knowledge from research and development organizations, financed from public sources, such as universities, academy of science and others, but also from the research organizations receiving contributions from the state budget, etc. The organizational forms of these organizations are diverse, ranging from e.g. centers established at particular universities up to different half-autonomous organizations and profit organizations.

Before taking a decision on what type of KTO this refers to, it will be necessary for a KTO founder to formulate its mission, which would include the objectives of the respective founder. The mission must be formulated so as to be understood and adopted by the following entities: the management and employees of the future KTO, the management of the respective founder (e.g. a university or a research institute), by the investigators, who are expected to be involved in the respective innovation process, industrial enterprises that should manufacture new products and introduce them to the market, by state administration bodies and local self-government authorities (especially regional ones), which are responsible for defining the public policy and which will often be in charge of providing financial subsidies to KTO. This mission is not always understood by the representatives of several involved parties, since the involved parties may include employees of the Academy of Science, employees of universities, departments of these organizations, but also students, government bodies (national and international), employees in the service sector e.g. experts in the field of patents, lawyers, national and multinational industrial companies, small and medium enterprises, financial institutions, risk capital owners and others. The problem does not lie in the fact that these entities do not understand the importance of KTO, but in the fact that each of these entities has its own interests and the creation of KTO may limit the interests of such involved parties.

Therefore, the formulation of the mission is rather difficult.

Although the detailed formulation of the mission may be differentiated depending on specific conditions, whether the local or other ones, the central idea of each KTO mission may be formulated as follows:

The central mission of knowledge transfer offices is to ensure the increase in the efficiency of the transfer of research and development results so as to achieve a maximum benefit for the society.

In formulating the mission in a particular case, various aspects may be taken into account and the key aspect should be determined so as to play the most important role in the KTO activities. Such aspects maybe:

- providing the transfer of results of the publicly-funded research into new products and services for the public use and nation wide benefits;

- promoting regional economic development and increasing the employment rate;
- for universities - promoting the development, maintaining the faculties and increasing the level of educational process;

- creating new or improving the existing relations with industry;

- generating new sources of funding for universities or research institutes based on the sponsored research, increasing the consultancy and expertise opportunities for universities and research institutes, obtaining either financial or non-financial ones (in the form of equipping these institutions with necessary facilities);

- serving as a service centre for the protection and exploitation of intellectual and industrial property;

- acting actively in order to facilitate the creation of spin-out businesses, scientific and technological parks, incubators and others;

- generating the network of income for KTO;

- creating conditions for effective implementation of the knowledge transfer, innovations, technologies and the results of development and research activities from universities, the Slovak Academy of Science and departmental development and research institutions to the economic practice (small and medium-sized companies and large companies in theregion);

- creating a marketing platform of development and research institutions to support obtaining financial resources - both the public and private ones;

- implementing lobbying of development and research institutions towards national institutions and European governmental institutions for achieving the objectives of KTO.

Regardless of the formulation of particular aspects of the KTO mission, it would be needed to incorporate an aspect to the KTO mission as mentioned in the above list, since this aspect creates a basis for managing the intellectual property, particularly in the organizations financed from the public sources.

\section{RESEARCH METHOD}

2. METODA ISTRAŽIVANJA

\subsection{Analysis of the current situation and} establishment of structure of research and development cluster (RDC)

2.1. Analiza trenutačne situacije i uspostavljanje strukture klastera za istraživanje i razvoj (RDC)

Primary tasks that must be determined in connection with the establishment of the Knowledge Transfer Office shall include:

- determining the nature of the office being established (legal and organizational type of the office)

- determining the amount of resources needed for fulfilling the task of the office and

- deciding how resources are to be used and created.

In advanced industrialized countries various organizational structures are established for the performance of tasks and missions of knowledge transfer offices. In general, they may be divided into three basic groups:

- offices that provide services of this nature only for one research organization, and they are generally a part of the development and research organization; 
- offices that are created as legally and organizationally separate entities that ensure transfer of knowledge of several scientific and research organizations and customers are considerably differentiated;

- offices that have come into existence and operate as profit-making-orientedentities and their organizational structure generally corresponds to the structure of economic organizations.

Based on the approved task of the $7^{\text {th }}$ Framework Programme, under which the transfer of knowledge is to be made, the RDC is an organization that can be included to the second group of organizations described in the above structuring. Based on this fact, the RDC will be aimed at promoting knowledge transfer to a larger number of research organizations, meaning on the other hand that it will operate separately (geographically and organizationally) from research organizations and, of course, from the researchers of these organizations, where the number of these researchers will be considerable and also the results of their research activities will be differentiated.

In this context, it should be noted that this form of organization requires close relations with the inventors and researchers, and the opportunities of knowledge transfer are so difficult that they can often lead to unfulfilled expectations which are typical for the establishment of RDC. On the other hand, this form of organization that represents acertain form of centralization of resources may finally be effective. It should be emphasized that the model for the knowledge transfer office is clearly conditioned by the formulation of mission and tasks of the RDC.

In connection with the establishment of such R \& D cluster, it is necessary to fulfill the following basic tasks:

- formulate a cluster mission;

- determine its organizational and legal model;

- define the method of acquiring resources for the cluster operation;

- define the relationship with research organizations and researchers;

- define the relationship with industry;

- define the relationship with government organizations and

- define the relationship with regional organizations in the area of the cluster acting.

\subsection{Cluster mission}

\subsection{Misija klastera}

In formulating the cluster mission, it is necessary to determine the cluster fundamental role and its additional tasks. The basic role of the RDC can be defined as follows:

Create the conditions and ensure the implementation of the transfer of knowledge and the results of scientific research activity from the area of the research funded by public sources, as well as sources of economic profit organizations and own resources of R \& D centers into the economic practice and thereby contribute to increasing the competitiveness of economic organizations. The target beneficiaries of such knowled- ge should mostly be small and medium-sized enterprises, which do not have the resources for both basic and extensive applied research.

Additional tasks and functions of RDC shall include:

- assisting in the planning of research tasks of scientific research organizations;

- ensuring that the results of scientific research tasks are placed to the international databases;

- creating the conditions for participation in the marketing survey in the area of ascertaining requirements of industrial practice for solving the urgent requirements and for the transfer of these requirements to R \& D centers;

- assisting in placing the results of scientific research activities into the implementation phase;

- co-participating in the transfer of knowledge to the economic practice and social development of a respective region;

- co-participating in the protection and exploitation of intellectual and industrial property by consulting and teaching activities, especially for small and medium-sized enterprises;

- advisory activities by which they will co-act in building spin-out businesses, incubators and scientific and technological parks in a respective region.

\subsection{Organizational and legal model of the} research and development cluster

2.3. Organizacijski i pravni model klastera za istraživanje i razvoj

A research and development cluster should be an economically and legally independent nonprofit organization focusing on the tasks referred to in the RDC mission. Organizational structure of the RDC will be flexible. However, in principal, the RDC should be an organization with few employees, whose organizational structure should be tailored to the tasks in 3 key areas:

- cluster management area, which would be necessary to solve the issues of the management of the cluster activity, economic problems of the cluster, the area of marketing and relationships with government and regional authorities, assistance insolving the problems of protection and exploitation of industrial and intellectual property in research organizations (the issue of ownership of the tasks being solved, legal issues relating to patents and others);

- the area of relations to scientific-research organizations; in this field this should refer primarily to the assistance to scientific research organizations in the planning of tasks, providing information on obtaining grants, placement of the results of research to international and national databases, ensuring that the results of scientific research activity will be transferred to the industrial practice;

- the area of industrial relations practice (small and medium-sized enterprises and big companies) as the main beneficiaries of the knowledge transfer. In this area the main activities of the RDC would be aimed primarily at identifying and influencing prospective plans of small and medium-sized enterprises with regard to the possibility of using the results of scientific research 


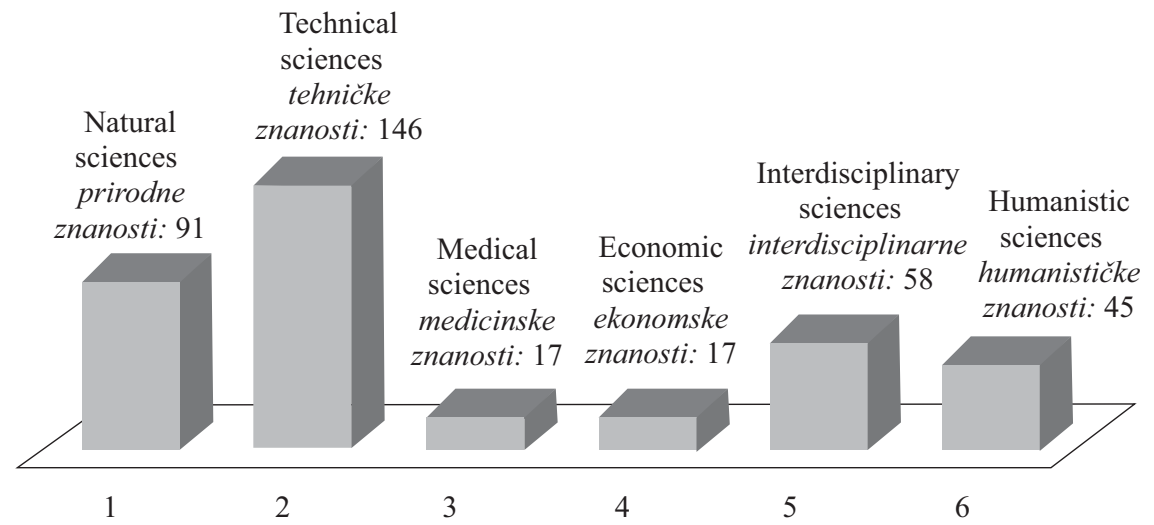

Figure 3 Number of investments in research and development in particular fields in the period 2006-2008 in Slovakia. Source: ŠÚ SR

Slika 3. Broj investicija u istraživanje i razvoj na pojedinim poljima znanosti u razdoblju 2006-2008.u Slovačkoj. Izvor: ŠU SR

tasks solved by the scientific research base of a respective region.

\subsection{Provision of sources for the cluster activity}

2.4. Pribavljanje sredstava za aktivnosti klastera

Experience from the advanced industrialized countries shows that the period until the office forknowledge transfer obtains sufficient funds to cover its activities lasts up to 10 years. On the other hand, it is necessary to take into account that the economic organizations in our country are at present focused mainly on short-term profits (Figure 2). These two assumptions result in problems with financing the activity of a research and development cluster. Especially in the initial period it is required, in the area of the RDC activities, to rely on a massive support from the structural funds, the support from government and regional authorities. E.g. in Canada the amount representing 7\% of the budget funds for science and research is determined to support knowledge transfer offices. The support of knowledge transfer is the main tool of using outputs from scientific research activities in a respective country (Figure 3). This means that in the initial period of the cluster activity, such activity should be financed mainly from the structural funds and the national budget. The second main source of cluster financing is the support of the regional authorities. The cluster activity within a respective region is a major tool for increasing the business competitiveness of a certain region (Figure 4) and thereby not only for improving the living standard of the respective region, but through the tax and levy policy, it is also the tool for increasing the region income. The third source of financing the cluster activities are members' contributions of individual members of the cluster.

Although it is probable that this should be the main source of revenues for the cluster, it is necessary to note that at present the formation of clusters has become popular and that each cluster expects contributions from its members. On the other hand, the impacts of the contribution of individual clusters on the economic results of thecluster members are minimal and consequently problems may be expected in this area already during the cluster establishment. From a long-term perspective, the cluster activity should be financed by a share of profits reached by the transfer of knowledge (whether in thefield of technology, new products and services, the share of profits of potential spin-out businesses, licenses, contracts with the industrial practice, or other forms of the transfer of know-how).

In this respect the position of the cluster, as an organization to ensure cooperation with a number of economic or scientific research organizations, is far more complex than the position of the organization (or

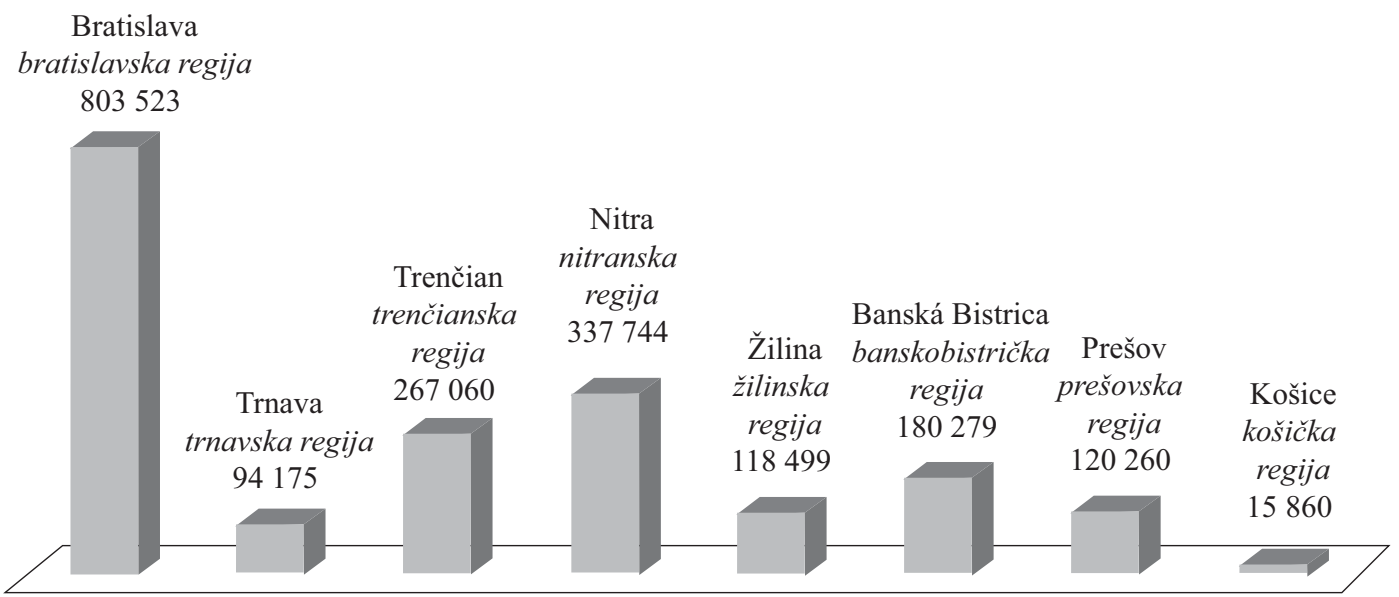

Figure 4 Investments in innovations for particular regions in Slovakia (in $1000 €$ ). Source: ŠÚ SR

Slika 4. Investicije u inovacije za pojedine regije u Slovačkoj (u tis. EUR). Izvor: ŠU SR 
the centre of technology transfer, etc.) operating as an organizational unit of a particular organization (e.g., university, etc.). Identification of resources and obtaining funds for the RDC is a task that in no case can be underestimated. In the first years of cluster operation, this task is regarded as the most complicated and most important task.

\section{RESEARCH RESULTS}

\section{REZULTATI ISTRAŽIVANJA}

\subsection{The basic precondition for the cluster} success - maintaining strategic cluster relationships

3.1. Osnovni preduvjeti za uspjeh klastera održavanje strateških odnosa klastera

In connection with the mission of R\&D cluster and its organizational structure, focus was placed on the issues of relations with major entities, with which the RDC has to maintain relations as a precondition for the success of the cluster. The main strategic relationships are the relationships with the following entities:

- relationships with scientific research institutes and centers, regardless of the sources of their funding and in this respect a non negligible role is played by researchers and inventors. In the effective transfer of knowledge into the business practice the RDC must professionally and methodically assist in solving the relations of the parties involved;

- relations with the private sector, which is a major suggested customer of outputs from scientific research activities;

- relations with the state administration bodies and local government bodies (Figure 5).

\subsubsection{Relations with scientific-research centers} 3.1.1. Odnosi sa znanstvenoistraživačkim centrima

The relationship with scientific research centers in terms of meeting the cluster mission is the most im- portant. Without the cooperation with these centers, where inventions, new technologies, designs of new products and knowledge are created, the transfer of knowledge to the industry would be impossible. Although it is not obvious at first sight, since the success and effectiveness of $R \& D$ centers depend on the work of inventor sand researchers, the aspect of influence (even the indirect one) cannot be marginal for the successful operation of the cluster. Therefore it is necessary to highlight the problems and the role of inventors and researchers and this will result in the possibility of cluster acting in this area.

This group of researchers is of such importance that without their active support and involvement in the tasks being solved it would be difficult to achieve any measurable result in this activity. In this context it is necessary for them to be interested in the achieved results and they should be provided with the help in the process of licensing and patenting and enabled to have personal contact with potential candidates for the license. It is also necessary to prove them that knowhow and show-how are an essential precondition for potential commercialization of the results of research activities. Since they are very busy individuals, it would be necessary to simplify the process of inventions and to provide them access to the senior staff of a research centre and contact with the cluster. This brief survey of the tasks that must be organized mostly by the management of a respective institution, also points out at the necessary technical and methodological assistance that should be provided to research organizations (the cluster members). The cluster should also help research organizations to create such relationships with the industry that would enable the flow of benefits from the industry to research institutes. These are mostly benefits such as sponsorship of research tasks, subsidies for equipment and facilities for the task being solved and others. The other aspect, not to be neglected, includes issues of the

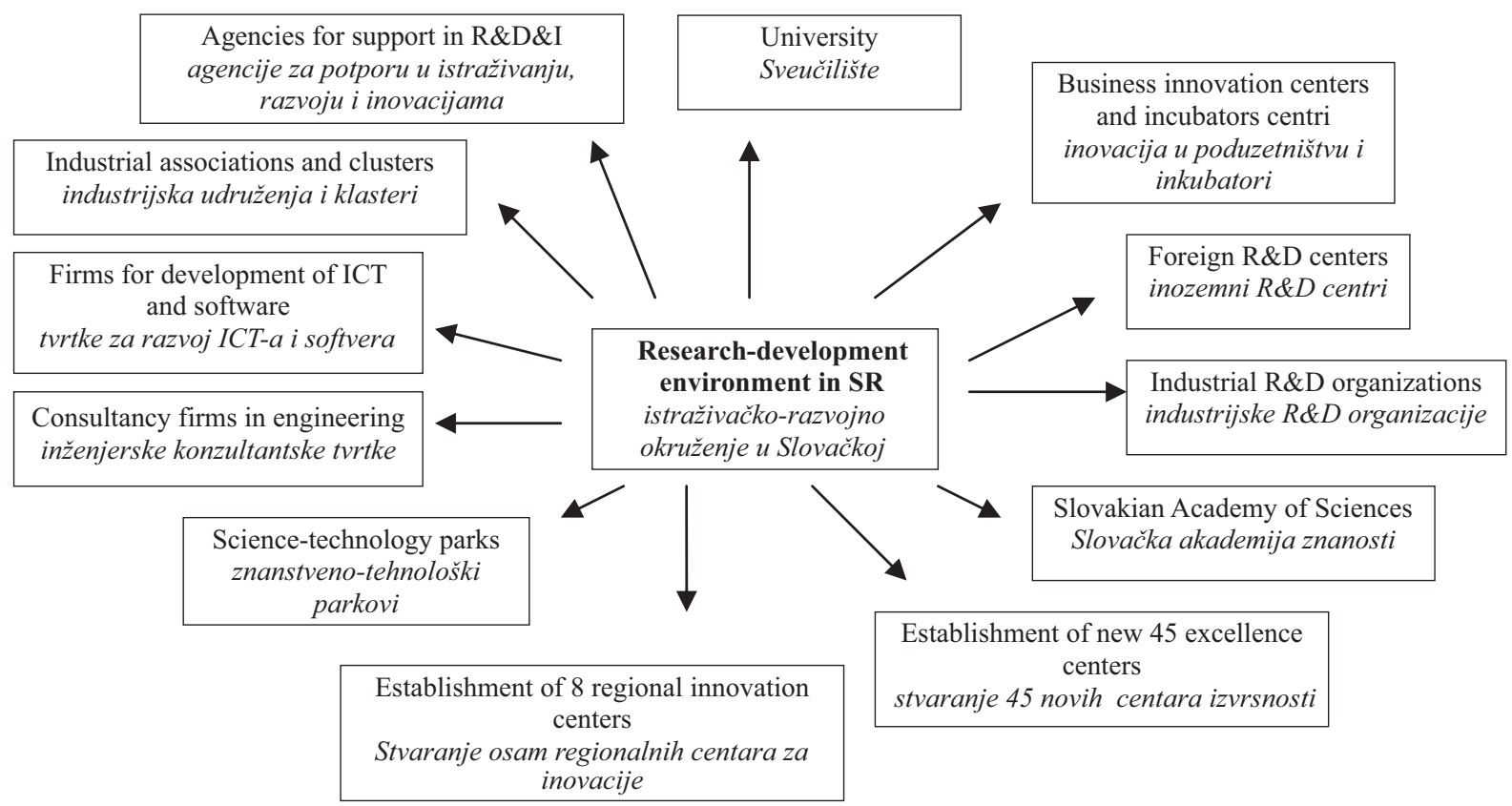

Figure 5 Structure of Slovakian research-development environment. Source: Kováč and Švač (2010)

Slika 5. Struktura slovačkoga istraživačko-razvojnog prostora. Izvor: Kováč i Švač (2010) 
protection of intellectual property, shares in the profits from licenses and other forms of incentives for researchers. In this sense the cluster should be in a position to provide advisory and educational activities in the respective fields. Examples of other possible cluster cooperation with research institutes include:

- help to provide background research for the patent in the planning stage of research or any other forms of protecting of already solved research tasks. The aim of this cooperation should lie in avoiding a duplicate solution of research tasks, since the experience shows that often up to $30 \%$ of the time spent on research is spent inefficiently due to the reason of duplicity.

- in relation to the protection of intellectual property, assistance in applying confidential or secret procedures in the tasks that lead to potential outcomes that may be commercialized;

- judge the outputs of scientific research works with regard to their possible licensing or patenting;

- assist in evaluation of outputs in terms of ownership of inventions and outputs of scientific research tasks; provide technical assistance in the field of patent procedure.

The above mentioned tasks are focused more on aid that the cluster should provide to the management of the research centre in relation to the researchers. However, the cluster has a key role in maintaining the relationship between the cluster and research centers in the following areas:

- participating in the provision of information on perspective areas of research in the sphere of acting of a respective scientific research institute;

- assisting the scientific-research organizations (cluster member) in commercialization of the outcomes of scientific-research activities of a respective organization;

- assisting members of the cluster in searching contacts with small and medium-sized businesses as the future users of the outcomes of scientific-research activities;

- placing information on the outcomes of scientificresearch activities of members of the cluster to international databases;
- assisting members of the cluster in establishing contacts and concluding contracts with foreign partners;

- provide counseling to members of the cluster on the protection and exploitation of intellectual and industrial property;

- organize educational activities for members of the cluster in the area of protection and exploitation of intellectual and industrial property with regard to EU legislation in this area.

\subsubsection{Relations with the private sector}

3.1.2. Odnosi sprivatnim sektorom

Relations in this area belong to the most important preconditions for the success of both R\&D cluster and knowledge transfer to the economic sphere. Industrial enterprises, whether large, medium-sized or small, are or should be the customers of the outcomes of scientific-research activities. The main focus of relationships with the industrial sector may be defined in the following way:

- searching for fields of common interest of the industrial sector and R\&D cluster in the implementation of the outcomes of scientific-research activities to the industrial practice, identifying demands of the industrial sector for scientific-research activity or mapping the areas of possible cooperation with the $\mathrm{R} \& \mathrm{D}$ cluster;

- entering into long-term cooperation contracts in the exploitation of outcomes of scientific-research activities with large enterprises and their parent companies;

- actively participating in the conclusion of licensing agreements between the members of the cluster and the industrial sector, taking into account EU legislation in this area;

- provide marketing activities in informing small and medium-sized enterprises about the outcomes of scientific-research activities and co-participating in any potential licensing negotiations;

- co-acting in establishing spin-out businesses in the research institutions financed from the public resources, particularly in universities, this still being the weakest point of knowledge transfer to the industrial use in our conditions.

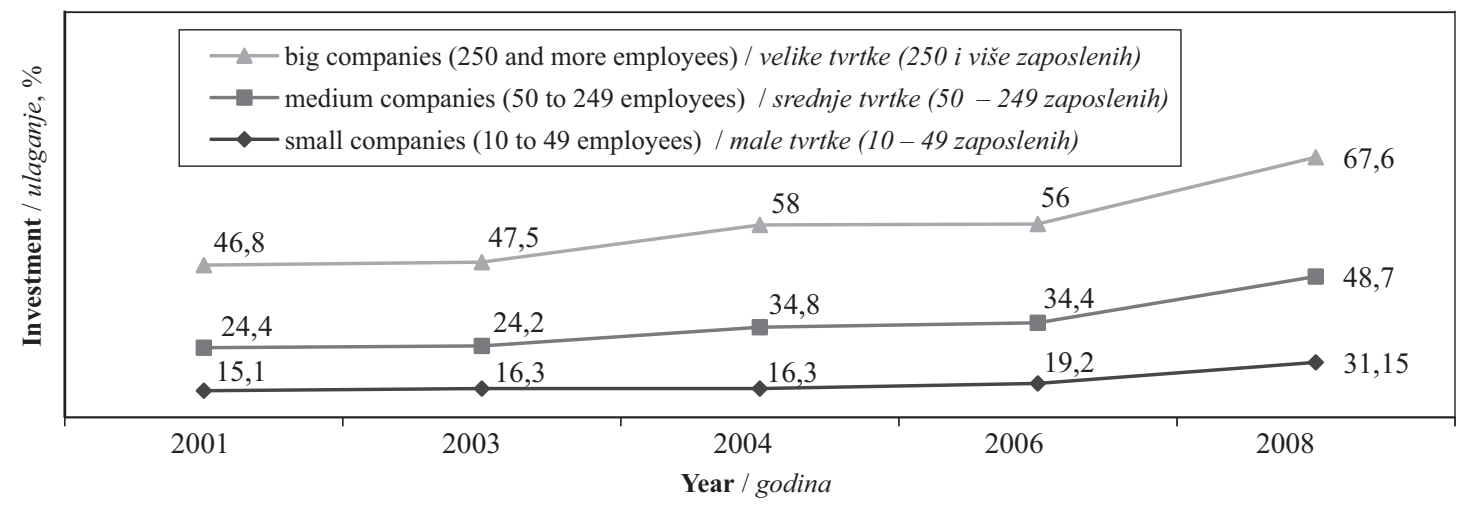

Figure 6 Trends of investments in research and development to companies for the period 2006-2008. Source: ŠU SR Slika 6. Trend ulaganja u istraživanje i razvoj u poduzećima za razdoblje 2006 - 2008. Izvor: ŠU SR 


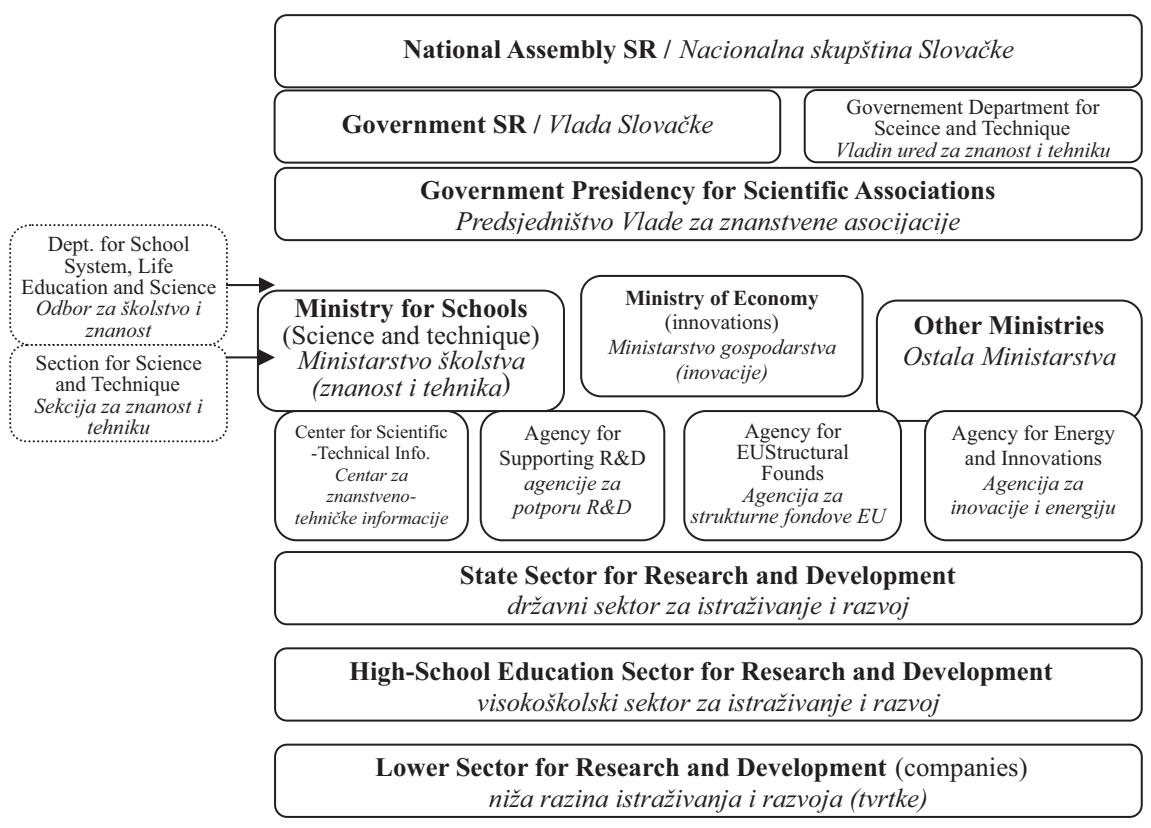

Figure 7 Management of state scientific-technical and innovation policy in Slovakia

Slika 7. Upravljanje državnom znanstveno-tehničkom i inovacijskom politikom u Slovačkoj

\subsubsection{Relations with government authorities and public administration bodies}

\subsubsection{Odnosi sdržavnim tijelima i tijelima javne uprave}

As mentioned in the introductory part, especially in the first phase of activity of R\&D cluster it is necessary to organize the operation of this cluster by providing the funds whether from the structural funds or from the state budget as well as from the funds of public administration bodies. On the other hand, it should be emphasized that the successful operation of the cluster results in increasing the competitiveness of industrial organizations in a respective region, as well as in the whole national economy, which will be also reflected in the growth of taxes and levies. For these reasons, the establishment of close and mutually beneficial relations between the cluster and the state and public administration bodies is one of the preconditions for the successful operation of the cluster. Specific relationship with the state authorities is the relationship with the Industrial Property Office of the Slovak Republic, which covers the whole area of intellectual property protection from the protection of inventions, substantive patent law, utility models, industrial designs and protection of commercial symbols. In this context, for the functioning of the cluster, it is necessary to achieve the position granting that:

- at least in the first 5 years, the cluster operation is also covered by the resources of these bodies (Figure 6);

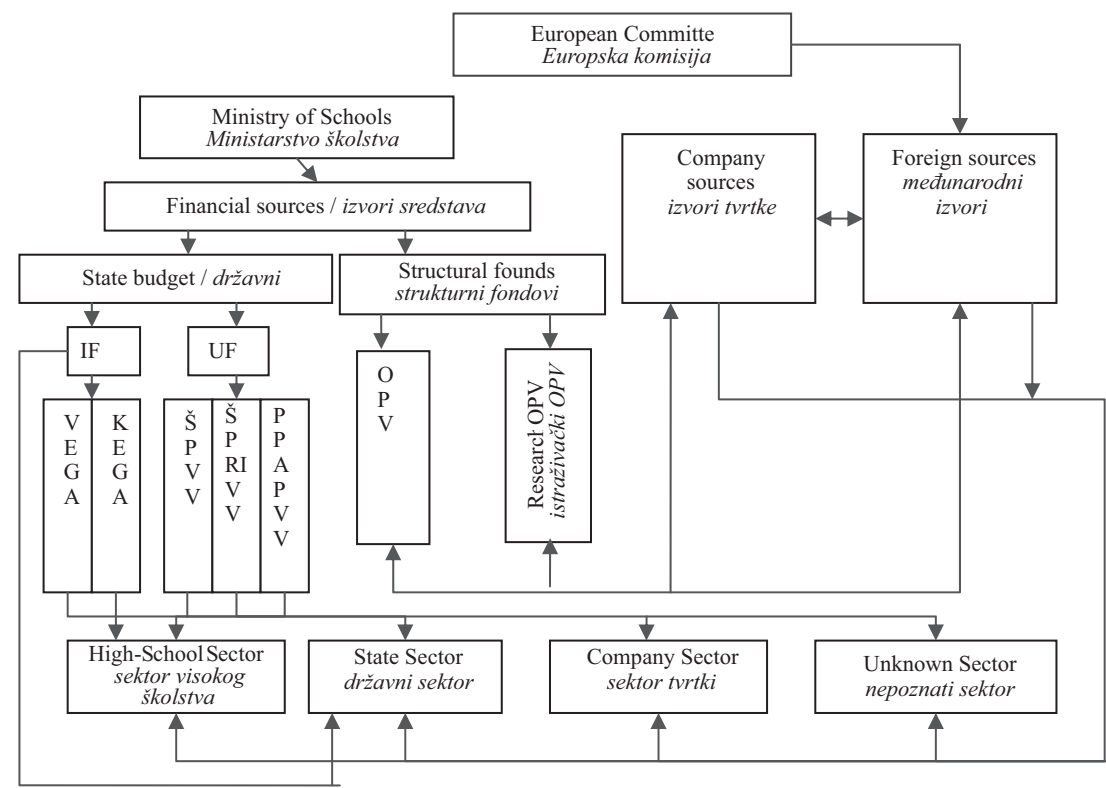

Figure 8 Scheme of financing science and research in Slovakia - Long-term plan of state scientific and technical policy until 2015

Slika 8. Shema financiranja znanosti i istraživanja u Slovačkoj - dugoročni plan državne politike za znanost i tehniku do 2015. godine 
Table1 Preview of expences for cluster implementation in the first 3 years

Tablica 1. Pregled troškova uvođenja klastera u prve tri godine

\begin{tabular}{|c|c|c|c|c|c|c|}
\hline \multirow{2}{*}{\multicolumn{4}{|c|}{ Cluster costs /Troškovi klastera }} & \multicolumn{3}{|c|}{$€$ per year / EUR u godini } \\
\hline & & & & \multirow{3}{*}{\begin{tabular}{r|}
2012 \\
234550 \\
\end{tabular}} & \multirow{3}{*}{\begin{tabular}{r|}
2013 \\
217230 \\
\end{tabular}} & \multirow{3}{*}{$\begin{array}{r}2014 \\
227933 \\
\end{array}$} \\
\hline \multicolumn{4}{|l|}{ Fix costs / Fiksni troškovi } & & & \\
\hline $\begin{array}{l}\text { Main planned costs (rough plan) / osnovni planirani } \\
\text { troškovi (grubi plan) }\end{array}$ & $\begin{array}{l}\text { Months } \\
\text { Mjeseci }\end{array}$ & $\begin{array}{c}\text { Persons } \\
\text { Osoba }\end{array}$ & $\begin{array}{c}€ / \text { month } \\
\text { EUR/mjesec }\end{array}$ & & & \\
\hline Manager / menadžer (direktor) & 12 & 1 & 3500 & 42000 & 44100 & 46305 \\
\hline $\begin{array}{l}\text { Project manager / projektni menadžer } \\
\text { (3 persons / } 3 \text { osobe) }\end{array}$ & 12 & 3 & 8700 & 104400 & 109620 & 115101 \\
\hline $\begin{array}{l}\text { Market-technical manager / trgovinsko-tehnički } \\
\text { menadžer }\end{array}$ & 12 & 1 & 2900 & 34800 & 36540 & 38364 \\
\hline Assistant / asistent & 12 & 1 & 1200 & 14400 & 15120 & 15876 \\
\hline \multicolumn{7}{|l|}{ Other / ostalo } \\
\hline \multicolumn{7}{|c|}{ Services purchesed on the market / usluge nabavljene na tržištu } \\
\hline Professional services / stručne usluge & 12 & & & 2500 & 2650 & 2800 \\
\hline Other needed services / druge potrebne usluge & 12 & & & 3000 & 3150 & 3307 \\
\hline \multicolumn{7}{|l|}{ Other main costs / ostali osnovni troškovi } \\
\hline \multicolumn{4}{|l|}{ - Assurance / osiguranje } & 200 & 200 & 200 \\
\hline \multicolumn{4}{|l|}{ - Tests and controls / testovi i kontrole } & 300 & 300 & 300 \\
\hline \multicolumn{4}{|l|}{ - Invoice audit / pregled računa } & 500 & 500 & 500 \\
\hline \multicolumn{4}{|l|}{ - Taxes and expences / porezi i nameti } & 0 & 0 & 0 \\
\hline \multicolumn{7}{|l|}{ Production overhead costs / proizvodna režija } \\
\hline \multicolumn{4}{|c|}{ - Stationery and office supplies / potrebni materijal i kancelarijski materijal } & 1000 & 1100 & 1200 \\
\hline \multicolumn{7}{|l|}{ Managers overhead costs / upravna režija } \\
\hline \multicolumn{4}{|c|}{ - Hygiene and cleaning supplies / materijal za čišćenje i higijenu } & 150 & 150 & 180 \\
\hline \multicolumn{4}{|l|}{ - Travel expences / putni troškovi } & 1000 & 1000 & 1000 \\
\hline \multicolumn{4}{|c|}{ - Telecommunication costs / telekomunikacijski troškovi (internet, ISDN, SIM) } & 1800 & 1800 & 1800 \\
\hline \multicolumn{4}{|l|}{ Rent for the offices / najam prostorija } & 15000 & 15300 & 15606 \\
\hline \multicolumn{4}{|l|}{ Purchase of techinque / nabavka tehničke opreme } & 4000 & 0 & 0 \\
\hline \multicolumn{4}{|l|}{ Purchase of furniture / nabavka namještaja } & 3500 & 0 & 0 \\
\hline \multicolumn{4}{|l|}{ Purchase of vehicle / nabavka vozila } & 20000 & 0 & 0 \\
\hline \multicolumn{4}{|l|}{ Variable costs / varijabilni troškovi } & 2450 & 2700 & 2950 \\
\hline \multicolumn{4}{|l|}{ Electric energy / električna energija } & 1000 & 1100 & 1200 \\
\hline \multicolumn{4}{|l|}{ Water / voda } & 150 & 160 & 170 \\
\hline \multicolumn{4}{|l|}{ Heating / grijanje } & 1000 & 1100 & 1200 \\
\hline \multicolumn{4}{|l|}{ Waste disposal / odvoz otpada } & 200 & 220 & 250 \\
\hline Hygiene and cleaning supplies / potrepštine za higijer & u i čišćenje & & & 100 & 120 & 130 \\
\hline Total costs per year / ukupni godišnji troškovi & & & & 237000 & 219930 & 230883 \\
\hline Fix costs / fiksni troškovi & & & & 234550 & 217230 & 227933 \\
\hline Variable costs / varijabilni troškovi & & & & 2450 & 2700 & 2950 \\
\hline
\end{tabular}

- such conditions are created that the respective public administration departments (departments of government and regional bodies) could be actively involved in the activities of the cluster as well as in the cluster bodies;

- operation of the cluster is transparent, both in the area of intentions and achievements;

- a regular and effective dialogue is maintained with public administration authorities on the operation of the cluster, the results of operations of the cluster, as well as the problems of implementing the cluster mission (Figure 7, Figure 8).

\subsection{Procedures and personnel hiring for the} cluster activity

3.2. Postupcii upošljavanje osoblja za aktivnosti klastera

The operation of the cluster assumes mastering of all managerial functions, including protection of intellectual and industrial property. Achieving this objec- tive entails the elaboration of major procedures for the cluster operation, as well as mastering of these procedures not only by internal but also external personnel involved in the cluster tasks. This is also a prerequisite for successful cooperation with all parties involved (sakeholders), especially with the public administration bodies and individual members of the cluster.

The practices that appear necessary for the operation of the cluster include:

- management of the ownership of inventions, patents and the outcomes of scientific-research activities;

- solving the issues of distributing the profit among individual parties involved;

- judgment and evaluation of proposed inventions and patents;

- rules for concluding the contracts between the clusters and its members, between the clusters and the enterprises to which the transfer of knowledge is headed; 
- portfolio management of inventions, patents and the outcomes of scientific-research activities;

- marketing activities both in terms of entry into the cluster, as well as in the area of products offered;

- obtaining and providing information for the members of the cluster about disposable risk capital;

- management of conflicts in the interest of parties involved and others.

The portfolio of critical roles in the effective management of intellectual and industrial property and its transfer into the economic sphere is very extensive. Performance of the tasksin this area assumes 5 basic forms of expertise:

- good and effective management of all aspects of intellectual and industrial property, inventorship and patent activities, but especially the transfer of such knowledge into industrial practice;

- effective handling of basic problems of such area of the science in which the cluster has the main line of its activities;

- correct understanding of the problems of individual sectors and building of new enterprises (spin-out businesses);

- excellent project management and mastering the tools and techniques of research management;

- managing of interpersonal management tools and methods in critical situations.

\section{CONCLUSIONS}

\section{ZAKLJUČAK}

This article is the result of solving the seventh EU Framework Programme „Emergence of Research Driven Cluster in Central Europe". The main objective was to create a research cluster focusing on knowledge transfer form research to SMEs.

The methodology for building such a cluster is to serve as a model for other countries in Central Europe. The main objective of the grant task was fulfilled. This was confirmed by the commission of the EU and problem solving has been approved.

The outputs of the project are interesting in this context in the area of wood industry.
Concerning the organizational structure of the cluster, it was pointed out that an easy organizational structure was suggested. The internal staff of the cluster will probably not be able to solve all the tasks mentioned in the section above. It is therefore necessary, when establishing the cluster bodies, to take into account the fact that the cluster bodies will not be able to assess and influence the activity of the cluster all by themselves, but they will also have to consider the engagement of external executive fellow workers. The last but not least, it should be noted that the cluster will need highly skilled employees for its work, but it will not be able to reward them in the manner of the organizations that reach very high profit. Therefore, it will also be necessary to take into account the forms of motivation of the cluster employees.

\section{REFERENCES}

\section{LITERATURA}

1. Linczényi, A; Nováková, R; Intellectual Property Rights in European Union Conditions, In: Marketing and Trade 2004, Proceedings, Zvolen.

2. European Commission, Expert Group Report, Strategic Use and Adaptation of Intellectual Property Rights Systems In Information and Comunications Technologiesbased Research,Luxembourg 2003.

3. European Commission, Expert Group Report, Management of Intellectual Property in Public Funded Research Organisations: Towards European Guidelines, Luxembourg, 2004

4. Kováč, Švač, 2010: Charakteristika vývoja prjiemyslu $\mathrm{z}$ roku 2010.

\section{Corressponding address:}

Doc. Ing. RENATA NOVÁKOVÁ, Ph.D.

University of Ss Cyril and Methodius in Trnava

Faculty of Mass Media Communication

Námestie Jozefa Herdu 2

91700 Trnava, SLOVAK REPUBLIC

e-mail: re.novakova@gmail.com 